\title{
WOMEN PORTRAYAL IN INDONESIAN FOLKLORES: A SEMIOTIC STUDY
}

\author{
Niswatin Nurul Hidayati \\ STAI Al Hikmah Tuban \\ Email: niswatinnh@gmail.com
}

\begin{abstract}
"Indonesia consists of many islands, tribes, and cultures, so that the folklores possessed by this country are diverse. For Indonesian people, those folklores are not only used as a tool of entertainment for children, but also as a device for adults in teaching values and norms of society. Most of the folklores tell about the relationship between woman and man, whether they are as husband and wife, parents and children, lovers, friends, and others. That kind of relationship is closely related to gender, especially about the woman's position. This writing analyzed about 15 Indonesian folklores and how women were portrayed or represented in those stories. In analyzing those folklores, the writer used descriptive qualitative research method, in which the writer concerned on how women were portrayed. From the analysis of the fifteen Indonesian folklores chosen randomly, it could be concluded that some folklores described women positively, but mostly described them negatively. Some folklore shows a woman who is smart, tough, wise and more concerned with the interests of others than herself. However, women are also described as negative figures, for example as stepmothers, as spirits, animals, objects of curses, and only doing domestic work (housework). Almost in every folklore above, it is stated that a female figure is a figure who has a beautiful face. So, it can be said that women are judged by their physical characteristics."
\end{abstract}

Keywords: folklore, gender, woman portrayal

\section{Background}

Folklores become an inseparable part of the lives of Indonesian people, especially children. Folklore is defined by Dundes as a wealth of tradition, literature, art, law, behavior and whatever is produced by the community collectively. The story is told from generation to generation. Today, the story is not only delivered by word of mouth, but has been written and published in the form of a book that has been read by thousands of Indonesian children. In fact, some folktales have been packaged and told in the form of films that air on television.

The Indonesian nation consisting of many islands, tribes, and cultures, and became one of the countries that have many folklores, for example, the story of the mas, the legend of Tangkuban Perahu, Bawang Merah dan Bawang Putih, Malin Kundang, and so on. These stories are not only entertainment for children, but also a means for adults to teach values or norms in society. This is because folklore shows or represents the way of life of a particular society. This is similar to what expressed by Putnam (1964) that "Folklore includes the 


\section{Niswatin Nurul Hidayati}

traditional elements of the way of life of a group of people and a creative expression is a part of this way of life." revealed by Bascom that the people's story has 4 functions as a projection system, as a means of ratifying cultural institutions and institutions, children's educational tools, and as a means of coercion and supervision so that the norms of society will always be obeyed by their collective members. ${ }^{1}$

In the story, there are quite a lot of folklore that contain stories about the relationship between men and women, both as husband and wife, parents-children, lovers, friends and so on. The relationship will be closely related to gender, especially about the position of women in these stories. Quite a lot is mentioned that women are considered as passive, illogical, talkative or have excessive emotions. Conversely, men are considered to be brave, logical, and have other qualities that are better or higher than women. Such stereotypes have even been described for a long time, for example from the findings of proverbs from several countries, for example the proverb from the Jews "Woman are nine times more talkative than men", Chinese "Three woman together make a theatrical performance, and Russian" The tongue is bubbling, but the head knows nothing about it"2

Apart from the function of folklore as an educational tool for certain moral or values in society, whether or not children who read, hear or even watch the story will absorb the portrayal of female characters in it, for example the evilness of a stepmother or sister stepfather, women only do homework, women can hurt their own siblings, and so on.

Folklore is owned by every country, both in the west and in the east. Many folktales from the West are well known in Indonesia because they have been displayed in books and films, for example Snow White, Cinderella, Hercules, and so on. In the story of Snow White, a story is told of a princess who would be killed by her stepmother through a hunter. However, because the hunter did not have the heart to carry out this heinous act, he let Snow White run into the forest where he was helped by 7 dwarves. When the stepmother found out that Snow White was still alive, he went to the forest and gave him a poisonous apple which made him unconscious. In the end, he can wake up again after being saved by a prince.

From the excerpt of the story above, it shows how women and men are portrayed in a story. In the story, the female character is portrayed as an evil stepmother who has the heart to kill her stepdaughter. In addition, Snow White is also described as a persecuted person and he gets a lot of help from many parties, for example, seven dwarves and princes. Meanwhile, the

\footnotetext{
${ }^{1}$ Rafiek. M. Teori Sastra: Kajian Teori dan Praktik (Bandung: PT Refika Aditama, 2012)

2 Jane Sunderland. Language and Gender: an Advanced Resource Book (New York: Routledge, 2006), 2-3
} 
male figure, in this case the prince, is described as a great figure because he is able to save a princess. The example above is an example of a story that originated from a western country that illustrates how men and women are in a story. In this short article, the author observes how women are in folklore in eastern countries, it is Indonesia.

There were many researches related to semiotic study, especially to the woman portrayal. The first research was carried out by Maya Diah Nirwana, Sigit Hermawan, Mudji Astuti, and Lusi Andriyani entitled "Pengembangan Model Representasi Perempuan dalam Media: Studi Kesetaraan Gender pada Reality Show Tema Cinta di Televisi untuk Meningkatkan Martabat Perempuan". The research published in Communication Journal showed that the woman was portrayed both positively and negatively. In the positive side, woman was portrayed as man who was able to work hard, open minded, sportive, optimist, and others. While in the negative side, the woman was portrayed as easily panic person, emotional, chosen due to her physical appearance, and others. The second research was conducted by Sekar Harumningtyas entitled "Penggambaran Perempuan melalui Bahasa Media Masa" in her thesis. Then, the third research was conducted by Eviyono Adi Wibowo entitled "Representasi Perempuan dalam Film Wanita Tetap Wanita (Analisis Semiotika Representasi Perempuan dalam Film Wanita Tetap Wanita).

From the three previous researches, it could be said that actualy they had similarities and differences from the current research. The similarity was that having the same theme related to the semiotic study in the woman portrayal in certain media. Then, related to the differences, the media which portrayed the woman were different. In the previous research, the media were in the reality show, television, media, and also film, but in the current research, the writer took Indonesia folklores as the object of the research. Moreover, the folklore used were from many areas in Indonesia. So, this article would be interesting to be read.

\section{Folklore}

In a paper entitled Folklore: A Key to Cultural Understanding mentions that folklore includes the way of life of a group of people and creative expressions that develop naturally as part of the way of life. ${ }^{3}$ John F. Putnam also added that folklore includes the beliefs believed by members of community groups and the actions they take come from that belief. It was also stated that "folklore is the product of a special form of verbal art."4 Folklore is characterized

\footnotetext{
${ }^{3}$ John F. Putnam. Folklore: A Key to Understanding (Association for Supervision and Curriculum Development, 1964)

4 Vladimir Propp. Theory and History of Folklore (Minneapolis: University of Minnesota Press, 1997)
} 


\section{Niswatin Nurul Hidayati}

by the absence of the writer or creator of the story, and usually it is not considered fiction but it is truly real. Propp also mentions that other characteristics of folklore are the spread usually by word of mouth, different from literary works which are usually spread in writing or manuscripts.

Folklore has several functions like what Bascom mentioned, they are: ${ }^{5}$ As a projection system, as a means of ratifying cultural institutions and institutions, children's educational tools, as a means of coercion and supervisor so that the norms of society will always be obeyed by their collective members.

Bruvan in Danandjaja ${ }^{6}$ stated that folklore is classified into three groups, they are oral folklore which is a folklore whose form is purely oral. Folklore genres that fall into this category are folk speech such as accent, nickname, traditional rank and title of nobility, traditional expressions such as proverbs, proverbs and quotes, traditional questions such as puzzles, folk poems such as poetry, and poetry, people's prose like myths, legends, and fairy tales, and the last is folk songs.

Then, partially oral folklore is folklore whose form is a mixture of verbal and nonverbal elements. People's trust such as superstition consists of statements that are verbal in nature plus gestures that are considered to have occult meanings. Then the last division is folklore whose form is not oral, although the way of making it is taught orally. This large group can be divided into two sub groups, they are the form of folklore which is classified as material and non-material.

\section{Semiotics}

In general, semiotics can be defined as a branch of science that studies the sign. Umberto Eco stated that "Semiotics is concerned with everything that can be taken as a sign". Semiotic studies do not only cover what are called "signs" in speech every day, but this study also includes anything that has other meanings for something. The sign can be in the form of words, images, sounds, gestures or objects. Contemporary semiotics do not study signs as something separate but as sign-systems, for example in the form of media or genre. They learn how meaning is made and how reality is represented. ${ }^{7}$

\footnotetext{
${ }^{5}$ Rafiek. M. Teori Sastra: Kajian Teori dan Praktik (Bandung: PT Refika Aditama, 2012)

${ }^{6}$ James Danandjaja. Folklor Indonesia: Ilmu Gosip, Dongeng, dan Lain-lain (Jakarta: Pustaka Utama Grafiti, 1997)

${ }^{7}$ Daniel Chandler. Semiotics The Basic. (London: Routledge, 2007).
} 
So, it can be said that semiotic studies can learn any sign as long as someone interprets the sign referring, representing or being a representation of something else. In this paper, the sign is in the form of text about the folklore of the archipelago in relation to the position of women in it. Readers of a literary work can make meaningless interpretations of the meanings contained in it. ${ }^{8}$ This meaning can be explored through a method called the "transaction mode" which contains five codes in it, they are hermeneutic code, semes code, symbolic code, proairetic code, and cultural code.

a. Hermeneutic code is the core codes that are the answers to the reader questions. This code is used if the reader catches a sign that requires deep interpretation. This code is usually found in many literary works which contain many figurative language content.

b. Semes code is the whole meaning of a work as a whole. In this code, the meaning of a work is interpreted thoroughly to find out the general message contained in it.

c. Symbolic code is symbols that represent other meanings of signs used. Like hermeneutic code, this code is also widely used in literary works that contain many figurative language content, such as poetry or poetry.

d. Proariretic code is a linear code that connects between parts in a work. A work is not delivered simultaneously, but through a collection of signs arranged in several parts. This code examines how these parts are united linearly.

e. Cultural code is a metalingual function of a work specifically a sign in it, which is related to culture and its expression.

\section{Indonesian Folklore}

In this short article, the author takes 15 Indonesian folklore as randomly selected data from the dongeng.org page, they are Batu Nong, The Origin of Ampean City, The Origin of Lombok, Legend of Pesut Mahakam, The Origin of Ruai Bird, Legend of Batu Hapu Mountain, Legend of Bidadari Lake, Nyai Anteh Sang Penunggu Bulan, Timun Mas, Lutung Kasarung, The Origin of Telaga Warna, Ratu Aji Bidara Putih, The Origin of Tangkuban Perahu Mountain, The Origin of Toba Lake, Prambanan Temple. In order to limit the scope of this article, the writer limited the analysis into some points, they were related to the position, relation, characters, also their role in the society.:

\footnotetext{
${ }^{8}$ Roland Barthes. Mythologies (London: Paladin, 1973).
} 


\section{Niswatin Nurul Hidayati}

\section{Analysis and Discussion}

As being stated in the previous part, in order to limit the scope of this article, the writer limited the analysis into some points, they were related to the position, relation, characters, also their role in the society. In Indonesian folklore, women were included in some positions, such as young girl, wife, queen, and soon. Then, related to their relationship with other person, they were related to their husband, king, parents, also society. In terms of characteristics, they were portrayed both physically and non-physically. They were also having roles in the society, including their relation toward the society, social and also cultural value. In the following points, the writer described the story in short version followed by the short description of women portrayal in those folklores.

\section{Batu Nong}

Batu Nong is a large stone located in Leko Village, Alas Subdistrict, Sumbawa Regency. According to the story, the stone used to come from a jar containing a snake. The snake had previously been a man who had broken the rules, that the men were taboo to wash their children's bottoms after defecating. The man violated the rules because he could not bear the smell of his son who had finished defecating, while his wife went to watch the crowd being held in a neighboring country. The wife thought that the country she was going to was not too far away, but it turned out to be not enough in a day trip and when she got there she was dissolved in pleasure. Because the wife did not immediately return home, the husband washed his son's butt and in the evening he got a curse of being a snake.

The main character of this folk tale is a husband and wife. The husband was described as a very loving person because he gave permission for him to watch the crowd. The husband was not angry when his wife came home late which caused him to be cured by washing his son's buttocks. Whereas the wife figure is described as a housewife who has never seen crowds since she was married, a submissive figure to her husband, but she is also a person who is negligent with her responsibilities when she is given the opportunity of her husband when he is allowed to leave the house.

\section{The Origin of Ampean City}

According to the story, Ampean City comes from the name Satria Tampena who is the son of Raden Satria Nata and his wife who is the daughter of the genie. The genie princess was previously captured by Raden Satria Nata because she always sucked the komak flower juice in the village. After that, the two married with an agreement that both parties would not talk to each other while being husband and wife. However, at one time the agreement was violated by Raden Satria Nata, so that his wife and child disappeared. Raden Satria Nata was encouraged 
to meditate so he could meet his son, but he could not meet his wife and could only hear his voice in the hermitage.

From the excerpts of the story above, it can be seen that women are portrayed as spirits (princess of genie) that harm villagers from sucking on komak flowers. The female figure is also described as an object, where the princess jinn is captured and made a wife by Raden Satria Nata. Like humans, the princess Jin also does homework, for example going to the temple to take water and to care for children. From here, it can be seen that women do domestic work.

\section{The Origin of Lombok}

According to the story, the name "Lombok" comes from the name Lomboq port which has the meaning "straight". This story comes from the legend of the Sasak people who stated that the work of the Old Mataram was led by a female king named Pramudawardhani who was married to Rakai Pikatan. The queen is a person who is an expert in government and his power has reached the island of Sumatra and the island of Flores. At that time, many people of Mataram sailed eastward through the Java Sea in junk boats. Because they continued to sail east and land at a port, the port was named Lomboq to commemorate their journey.

From the footage of the story above, it can be concluded that the figure of a woman is described as a figure of a royal leader and very expert in the field of government. The territory of the kingdom he led was also very wide to Sumatrra and Flores.

\section{Legend of Pesut Mahakam}

This story begins with a small family that has lived in harmony for years. However, one day the mother developed an illness and died. After that the father dissolved in sadness, until he met a beautiful girl who later became his wife. Finally the father worked again assisted by his children, while the stepfather stayed at home preparing food. However, then the stepmother's attitude is not good for children. He likes to order you to do difficult things. Until one day the stepmother and father left the house with all the property, so the child did not find anything when he came home looking for wood. For days they searched for their parents until they were hungry, until they finally found a new hut they believed to be their parents' house. Because they were too hungry, they went into the kitchen and ate the rice in the pot on a burning fire. Because the food is hot, their body temperature becomes hot which makes them run for the river. When heading to the river, the stems of the banana trees they embrace wither and burn, until then they find a river and plunge into it and they become fish. That fish is called Pasut or Pesut fish.

In the story above, the female character is portrayed as an evil person, namely as a stepmother who likes to give difficult tasks to her stepson. Women are also portrayed as 


\section{Niswatin Nurul Hidayati}

beautiful people who attract the attention of the father to remarry. As stated in the story that the stepmother lives at home to prepare food, so it can be said that women do domestic work.

\section{The Origin of Ruai Bird}

This story comes from Sambas Regency, West Kalimantan. According to the story, Ruai is a king's daughter, the youngest of 7 siblings who has a good personality. In contrast, the youngest six siblings have envy, envy, laziness to work and dislike parents. Because of that, the King really loved the youngest, and often scolded his siblings for their behavior. The youngest is often tormented by his brothers, but he cannot fight and can only cry and hopes that his mother is still alive will surely be able to protect him. At one point, the King left the palace for a reason for a month, and temporarily handed over to the youngest. This makes the brothers angry and have bad intentions to kill him. Then, they invited the youngest to find fish in the cave and then left him in the cave so he got lost. After seven days and nights, a grandfather appeared in the cave, the grandfather turned the youngest princess into a bird and named him Ruai, so he could fly out of the cave and watch his brothers punished by the king for killing him.

In the story above, the majority of the figures shown are female figures. it can be seen that the female figure is portrayed as a good person (the youngest), obedient, not brave enough to oppose her brothers and expect protection. Another figure is depicted as an antagonist who has jealousy, envy, misdeeds to his half-brother.

\section{The Origin of Batu Hapu Mountain}

This story comes from Tapin Regency, South Kalimantan Province. According to the story, Batu Hapu Mountain was once a man named Angui who was cursed by his mother because he did not recognize his mother after he became a wealthy merchant. Angui used to live with her mother who was a poor widow who had to work hard to meet their needs. Even so, he never complained. At one point, a Keling merchant passed by and saw Angui and was interested in adopting him. The mother, I arrived, finally let her go. With an adequate life with the merchant, Angui is a lazy, naughty and wasteful person. So, he was expelled by the merchant. After that Angui realized and started his own business and became a wealthy merchant. After that, he returned to his hometown with his wife and bodyguards. When he saw his poor mother, he did not admit and asked his bodyguard to drive the mother away. That's why the mother asked God to curse her child.

From the story above, we can see how a woman's figure is depicted, namely as a poor widow. Namu, he was also drawn by the idea that he had never given up hope of earning a 
living for his child. Later, at the end of the story, he was also described as a mother who cursed her own child.

\section{The Origin of Bidadari Lake}

The lake referred to in this story is located in Sungai Raya, which is located eight kilometers from Kandangan City, South Kalimantan Province. The story begins with a young man named Awang Sukma who sees seven young and beautiful princesses who descend from the sky and fly to the lake. Then, he took one of the princess's clothes and hid it in the tub so that the princess could not return to heaven. Then, Awang Sukma helped the princess and asked her to stay with her. In the end Awang Sukma proposed to the princess and they were blessed with a beautiful daughter named Kumalasari who inherited her mother's face, skin and beauty. However, in the end, the princess learned that her clothes were hidden inside the garden. After that, he left his husband and child.

From the story above, female characters are portrayed as beautiful princesses who can attract men named Awang Sukma. He was also described as a woman who left her child and husband after finding her clothes in the tub and returning to heaven.

\section{Nyai Anteh Sang Penunggu Bulan}

The story begins with the story of two teenage girls who live in the Pakuan royal palace, namely Endahwarni who is a heir to the throne of work and Nyai Anteh who is the daughter of a queen's favorite lady-in-waiting. Endwarwar has considered Anteh as his own sister without distinguishing their social status. One day, Endahwarni said that she felt jealous of Anteh because she was more beautiful and there would certainly be many proposals who came to her if she were a princess. At one point, the queen said that Endahwarni would be married to a man named Anantakusuma before he continued his father's throne. But apparently Anantakusuma was captivated by the beauty of Nyai Anteh. This made Princess Endahwarni feel hurt and drove Anteh out of the palace. After leaving the palace, Anteh became a famous tailor. Time has passed and the princess is looking for Anteh to take her back to the palace and make her a palace tailor. But it turned out that Anantakusuma still loved Anteh and this scared him. At one point, Anteh ran away from Anantakusuma's pursuit and he begged God to be saved. Then there is the force that draws it to the moon. So that he is called Nyai Anteh the watchman of the month.

In the story above, women are portrayed as figures who consider beauty to be very important which makes Endahwarni feel jealous of Anteh. In addition, a woman's marriage is also determined by the parents. In addition, Endahwarni who is a candidate for the inheritance of the kingdom, where the condition for leading his country is that he must marry first. 


\section{Niswatin Nurul Hidayati}

\section{Timun Mas}

Timun Mas story is one of the most famous stories in Indonesia. This story tells about a married couple who really want a child. So they pray everyday to God to get it immediately. At one point, the giant heard their prayer and he gave the cucumber seeds to the couple. He said that the seeds would later give the daughter to them, but he required that when the age of their child was 17 years, it must be left to the giant. When Timun Mas was 17 years old, the giant came to collect an appointment, but the couple told Timun Mas to go with him with salt, chili, cucumber seeds and shrimp paste. These objects are magical objects that become a trap for the giant and finally he drowns.

Timun Mas's story shows the persistence of a woman against a giant. He was described as a formidable figure who finally the giant died drowned when chasing him.

\section{Lutung Kasarung}

The story begins with the 7 daughters of Prabu Tapa Agung, they are Purbararang, Purbadewata, Purbaendah, Purbakancana, Purbamanik, Purbaleuih, and the youngest Purbasari. Purbararang as the eldest daughter of the king had an arrogant and cruel character so the king considered it inappropriate to lead the kingdom. One day the king dreamed and in his dream, Sunan Ambu who lived in heaven said that the throne should be given to Purbasari. The king's decision to make Purbasari his successor made Purbararang angry and planned bad things to win the kingdom. He spouted boreh (black substance from plants) onto Purbasari's face which turned black into black so that no one knew him. So he was expelled from the palace and thrown into the forest. This was heard by the heaven that made Sunan Ambu. Then, he took down his son Guruminda who wanted to have a wife as beautiful as his mother to come down to earth, but he had to disguise himself as a langur. Short story, he met Purbasari and helped him. He made Salaka Latrine for the princess where the water can restore her black face to white glow. After that, the princess was also given a gift, in the form of clothes equipped with beautiful jewelry.

News about the existence of a small hut that turned into a palace surrounded by flowers, as well as the existence of salaka latrines that reached the beautiful Purbararang ears which made him want to challenge Purbasari. He won Purbasari to compete in making public relations, competing in beauty, competing in long hair, sliming his waist, and looking good at prospective husbands. After that, langur turned back into a handsome and mighty Guruminda. After winning all the matches, Purbasari ruled the kingdom skillfully and wisely with the help of Guruminda. 
From the story above, it can be seen how some female figures are portrayed, for example Purbasari as a figure who has good and beautiful character, then, Purbararang who is portrayed as an arrogant, cruel, and want to harm his own siblings. while Sunan Ambu is described as a wise woman. In the story above, it also shows that being beautiful, having long hair, slim waist, and a handsome husband is a pride for women. This can be seen in the competition between Purbasari and Purbararang. In addition, female figures are portrayed as men who depend on men, for example Purbasari to Guruminda and Purbararang with her future husband.

\section{The Origin of Telaga Warna}

This story starts from King Suwartalaya and Queen Purbamanah who really want a child. After all this time, finally the queen conceived and gave birth to a daughter named Gilang Rukmini. The princess grows up to be a beautiful girl and she gets whatever she wants from her parents. This makes it a spoiled, angry girl and even often says harsh words if her wishes are not fulfilled. The King prepared a gift in the form of a very beautiful necklace for his daughter, but when his birthday arrived the princess threw away the necklace because he did not like it. The necklace was broken and the gold was scattered on the floor. Because the queen's deed was very sad and began to cry, so did the people all crying. They continued to cry even from the ground out of the water which continued to flood the kingdom and finally drowned the kingdom which then formed a beautiful lake. Some people believe that the colors of the lake come from the princess's necklace on the bottom of the lake.

There are two female characters mentioned in the story in the bag, namely the queen and the princess. The queen is described as a gentle figure who easily cries, while the figure of the princess is depicted as a beautiful girl who has a spoiled, angry, impolite, and rude words.

\section{Ratu Aji Bidara Putih}

Ratu Aji Bidara Putih is a queen from the land of Muara Kaman who has a beautiful face. He also has a wise and graceful person. These advantages have been heard everywhere so many want to prepare them. However, he still did not want to get married and wanted to further his country. Once upon a time, there came a ship owned by a prince from China who was famous for his wealth. The prince intended to propose to the queen, so he sent his envoy to deliver the proposal, but this time he did not immediately refuse and ordered one of his retainers to investigate the prince. The retainer told the Queen that the prince from China was a demon. He considered this because he heard how the prince drank wine which reminded him of a pig in the forest when drinking water. Finally, the queen refused her proposal and it made the prince angry and attacked the kingdom. The position of the queen and her kingdom was 


\section{Niswatin Nurul Hidayati}

squeezed, then she weaved and chewed betel nut, then chewed it tightly and she threw it into the arena of battle. Betel turned into giant numbers of centipedes and attacked Chinese soldiers. Finally they ran towards the ship. Then, the centipedes turned the ship and sank it.

From the story above, we can see how the figure of a woman who is portrayed as a beautiful, wise, thorough, in no hurry to make a decision. He is also a woman who is more concerned with the affairs of the state and its people than his personal interests, namely his own marriage.

\section{The Origin of Tangkuban Perahu Mountain}

Tangkuban Perahu is believed to be a boat that is overturned by the community. This story starts from Raja Sungging Perbangkara who goes hunting. When he was in the middle of the forest he dumped urine which was contained in caring leaves. Apparently, a female wild pig named Wayung who drank it and then gave birth to a beautiful baby who was later given the name Dayang Sumbi or Rarasati. Because of its beauty, there are many kings who ask for their hand, but none of them receive it. This resulted in a war between them. Because of this, Dayang Sumbi chose to isolate himself accompanied by a dog, Tumang. One day, when he played Torak, he dropped it and promised that anyone who took it would become her husband. Apparently, Tumang took the object and finally married the dog and had a son named Sangkuriang.

One time, Sangkuriang went hunting and told Tumang to chase the Wayungyang pig, but he did not obey. This made Sangkuriang angry and killed him. He took home Tumang's meat and then cooked it by his mother. When he learned about this he was very angry and hit Sangkuriang's head, then drove him away. Sangkuriang continues to go east and finally returns again and he meets the beautiful princess who made him fall in love who is actually his own mother. Dayang Sumbi tried to explain the misunderstanding but Sangkuriang still insisted on wanting to marry her. Finally Dayang Sumbi required that he make a boat and lake overnight by damming the Citarum River. Dayang Sumbi begged Sang Hyang Tunggal to make Sangkuriang unsuccessful, so he spread the slices of boeh rarang and then dawn broke. This made Sangkuriang angry and kicked the boat he was working to the north and tangible Tangkuban Perahu Gun.

The main female characters who appear in the story are Wuyangyang and Dayang Sumbi. In the story above, a female character is shown as an animal, in the form of a pig who is the mother of Dayang Sumbi. In addition, a beautiful physical description of a person was also illustrated through Dayang Sumbi's face, which became a fascination for men. He was also 
described as someone who did not think before acting or saying something when he promised to marry anyone who took his fallen Torak. Finally he married his own pet, Si Tumang.

\section{The Origin of Toba Lake}

Toba comes from the name of a farmer. The origin of Lake Toba was when Toba went fishing one afternoon and finally got a big one. When he brought home the fish, the fish turned into a beautiful girl. Finally, the two married on the condition that Toba would never bring up the origin of the fish. One year after the marriage, they were blessed with a son named Samosir. One day, the mother told Samosir to deliver food to her father. However, the father was angry because the rice given to him was low and left over, the father said that Samosir was a descendant of women from fish. Samosir cried while running home and told his mother everything. The mother was very sad and told her child to immediately climb the hill. When his child was almost at the top of the hill, the mother ran towards the river and jumped into it. after that he turns into a fish. At that time the very heavy rain and puddles became lakes, while the small island in the middle was called Samosir Island.

In the story above, there is only one female character, namely the wife of Toba, who is a fish. So, it can be seen that women are described as fish figures. In addition, Toba's wife is also described as a very beautiful female figure.

\section{Prambanan Temple}

The story of Prambanan Temple will not be separated from Raden Bandung Bondowoso and Princess Loro Jonggrang. At that time, when Raden Bandung Bondowoso chased Patih Gupolo to Boko Palace, he was very surprised when he saw the beauty of Princess Loro Jonggrang and wanted to marry him. However, he did not want it because the Raden had killed his father, Prabu Boko. To reject the proposal, he had a strategy by asking for Jalatunda wells and 1000 temples to be made in one night. Sang Raden agreed to the request. After the well was finished, the princess ordered her to go inside and ask Patih Gupolo to hoard it. But apparently he did not die in it. When the Raden built the temple, Putri Loro Jonggrang ordered the girls to pound and burn the straw to make it look bright and easy to crow alternately. Hearing that, the genies made the temple go away. Even so, the raden hunch said that it wasn't morning yet. Then, he asked the princess to count the temple and it turned out that the number was 999 temples. Therefore, he did not want to be edited by Raden Bandung Bondowoso. Having been mocked, he was very angry and cursed the princess into a statue of a stone statue fulfilling the 999 temples that there were 1,000 temples.

From the story above, women are very beautiful figures that make the Raden fall in love. He was also described as a clever and clever figure in finding reasons to refuse requests. 


\section{Niswatin Nurul Hidayati}

In addition, women also became objects, namely when he was condemned to become a statue by Raden Bandung Bondowoso.

Umberto Eco (1976) states that "Semiotics is concerned with everything that can be taken as a sign". So, it can be said that text or language is also a sign, that is a sign that represents something. Language is called representational system, because in language someone uses signs and symbols to represent concepts, ideas, and feelings to others. ${ }^{9}$ Representation can also be interpreted as using language to express something meaningful or to represent something to be conveyed to others. This representation theory is related to the stereotypes of society about men and women.

The community has a stereotype of men and women, for example men have a firm, courageous attitude, have a high position, are clever, and so on. Whereas women are second class (second sex) or subordinate class, weak, not confident, not smart, obedient, female success is judged by their physical appearance, and happy to gossip. ${ }^{101112}$

Cambridge Advanced Learner Dictionary defines stereotype as an idea or opinion about how something is shaped or how someone is behaving. Stereotypes are how one interprets a person's behavior, one's personality, or anything else based on what the community believes in general and this applies to the whole group. ${ }^{13}$

The same thing also revealed that stereotyping is labeling or marking a group. ${ }^{14} \mathrm{He}$ also added that stereotypes always lead to injustices originating from a gender perspective.

Such things are found in folklore, especially folklore in Indonesia. In the previous presentation, it was mentioned that the stories of several folklore folktales describe how the female figure is depicted.

\section{Conclusion}

From the explanation above, it can be concluded that folklore is a sign that can represent or describe something, in this case it describes the position of women in society. Folk stories

\footnotetext{
${ }^{9}$ Stuart Hall. Representation: Cultural Representations and Signifying Practices. (London: SAGE Publication Ltd., 1997)

${ }^{10}$ Janet Holmes. An Introduction to Sociolinguistics. (Longman Publishing: New York, 1995)

${ }^{11}$ Robin Tolmach Lakoff. Language and Woman's Place. (New York: Harper \& Row Publisher, 1975)

${ }^{12}$ Michael, Edwin., Bakar, Afi Roshezry Abu., Ibrahim, Ira Meilita., Veerappan, Geetha., Noor, Norazleen Mohamad., Heng Lim Ean., Latif, Taufik., Yann, Ng Kar. 2012. "A Comparative Study of Gender Roles in Animated Films". Global Journal of Human Social Science Volume 12 Issue 5 Version 1.0 Maret 2012. Global Journals Inc (USA).

${ }^{13}$ Mary Talbot. Gender Stereotypes: Reproduction and Challenge dalam The Handbook of Language and Gender oleh Janet Holmes dan Miriam Meyerhoff. (USA: Blackwell Publishing Ltd., 2003)

${ }^{14}$ Mansour Fakih. Analisis Gender dan Transformasi Sosial. (Yogyakarta: Pustaka Pelajar, 1996)
} 
can indeed be the right tool for children's educational facilities as a way of transmitting the good values that exist in society. However, there are some things that might be a "record" that in the story, directly or indirectly gives understanding to the child about how men and women are portrayed, so that there is a need for direction for children regarding this matter.

Of the 15 folklores shown above, it appears that women are portrayed positively and negatively. Some folklore shows a woman who is smart, tough, wise and more concerned with the interests of others than herself. This description can be seen in the story of Timun Mas, the Origin of Lombok, and Ratu Aji Bidara Putih. However, women are also described as negative figures, for example as stepmothers, as spirits, animals, objects of curses, and only doing domestic work (housework). Almost in every folklore above, it is stated that a female figure is a figure who has a beautiful face. This, it can be said that women are judged by their characteristics. This kind of depiction also appears clearly in Lutung Kasarung, where there is a competition between Purbasari (protagonist) and Purbararang (antagonist) who compares facial beauty, hair length, waist size, and good looks from the prospective husband respectively.

From the analysis of the fifteen folklores above, it can be seen that woman was portrayed positively as wise person Ratu Aji Bidara Putih, in which she was a queen in great kingdom. Then, in other story, women were also portrayed as tough person when they were facing much problems, such as in Timun Mas when she had to face the giant and finally she was able to defeat the giant. In contrast, mostly, women were portrayed negatively when they were related to their husband in a marriage, in which the women were always described as persons who did the housework, as cruel stepmother, and so on.

\section{REFERENCES}

Barthes. Roland. 1973. Mythologies. London: Paladin.

Chandler, Daniel. 2007. Semiotics The Basic. London: Routledge

Danandjaja, James. 1997. Folklor Indonesia: Ilmu Gosip, Dongeng dan Lain-lain. Jakarta: Pustaka Utama Grafiti

Endraswara, Suwardi. 2009. Metodologi Penelitian Folklore. Yogyakarta: Media Presindo

Fakih, Mansour. 1996. Analisis Gender dan Transformasi Sosial. Yogyakarta: Pustaka Pelajar.

Hall, Stuart. 1997. Representation: Cultural Representations and Signifying Practices. London: SAGE Publication Ltd.

Harumningtyas, Sekar. 2014. "Penggambaran Perempuan Melalui Bahasa Media Massa" (Skripsi, Departemen Ilmu Komunikasi Periklanan Fakultas Ilmu Sosial dan Ilmu Politik Universitas Indonesia)

Holmes, Janet. 1995. An Introduction to Sociolinguistics. Longman Publishing: New York. Karolus, Mike Lusye. 2013. Perempuan dalam Dongeng (Perspektif Komunikasi dengan Pendekatan Analisis Wacana Kritis) dalam Prosiding Seminar Internasional Studi Bahasa dari Berbagai Perspektif. Program Studi S2 Linguistik UGM Yogyakarta 


\section{Niswatin Nurul Hidayati}

Lakoff, Robin Tolmach. 1975. Language and Woman's Place. New York: Harper \& Row Publisher.

Michael, Edwin., Bakar, Afi Roshezry Abu., Ibrahim, Ira Meilita., Veerappan, Geetha., Noor, Norazleen Mohamad., Heng Lim Ean., Latif, Taufik., Yann, Ng Kar. 2012. "A Comparative Study of Gender Roles in Animated Films". Global Journal of Human Social Science Volume 12 Issue 5 Version 1.0 Maret 2012. Global Journals Inc (USA). Niwana, Maya Diah., Hermawan, Sigit., Astuti, Mudji., dan Andriyani, Lusi. "Pengembangan Model Representasi Perempuan dalam Media: Studi Kesetaraan Gender pada Reality Show Tema Cinta di Televisi untuk Meningkatkan Martabat Perempuan” Jurnal Ilmu Komunikasi Volume. 1., No. 2 (Oktober, 2011) ISSN: 2088-981X

Propp, Vladimir. 1997. Theory and History of Folklore. Minneapolis: University of Minnesota Press

Putnam, John F. 1964. Folklore: A Key to Understanding. Association for Supervision and Curriculum Development

Rafiek. M. 2012. Teori Sastra: Kajian Teori dan Praktik. Bandung: PT Refika Aditama

Setiyanti, Lusi., Angraini, Ria., Istiqomah, Erma., dan Nurfaizah. 2013. Bahasa Pencitraan Islam dalam Film Taken (2008) dan Taken 2 (2012) (Analisis Semiotik) dalam Prosiding Seminar Internasional Studi Bahasa dari Berbagai Perspektif. Program Studi S2 Linguistik UGM Yogyakarta.

Sunderland, Jane. 2006. Language and Gender: an Advanced Resource Book. New York: Routledge.

Talbot, Mary. 2003. Gender Stereotypes: Reproduction and Challenge dalam The Handbook of Language and Gender oleh Janet Holmes dan Miriam Meyerhoff. USA: Blackwell Publishing Ltd.

Wibowo, Eviyono Adi. 2015. "Representasi Perempuan dalam Film Wanita Tetap Wanita (Analisis Semiotika Representasi Perempuan dalam Film Wanita Tetap Wanita" (Skripsi, Program Studi Ilmu Komunikasi Fakultas Komunikasi dan Informatika Universitas Muhammadiyah Surakarta)

\section{Website}

Dongeng.org 